\title{
Upaya Meningkatkan Hasil Belajar Gerak Meroda Dalam Senam Lantai Melalui Media Bola Gymnastic Pada Siswa Kelas VIII MTs Roudlotul Mutta'allimin
}

\author{
Ahmad Murtaqi', Dadang Mubin², Wawan Setiawan ${ }^{3}$ \\ 1,2,3Fakultas Olahraga dan Kesehatan \\ 1,2,3Universitas PGRI Banyuwangi \\ Email: ahmadmurtaqi95@gmail.com
}

\begin{abstract}
ABSTRAK
Penelitian ini bertujuan untuk mengupayakan peningkatan gerak meroda dalam senam lantai melalui media bola gymnastic pada siswa kelas VIII. Penelitian ini merupakan penelitian Penelitian Tindakan Kelas (PTK). Penelitian ini dilakukan dengan subjek 24 siswa kelas VIII. Adapun desain penelitian ini menggunakan sistem siklus yang berisikan perencanaan, pelaksanaan tindakan, observasi, dan refleksi. Instrumen penilaian yang digunakan dalam penelitian yaitu rubrik penilaian gerak meroda (aspek psikomotorik), lembar pengamatan PTK (aspek afektif) dan lembar aspek kognitif. Teknik analisis data dalam penelitian ini dihitung dengan rumus untuk memperoleh hasil belajar. Berdasarkan hasil penelitian ini data awal diperoleh 7 siswa tuntas belajar dan 17 siswa tidak tuntas belajar. Pada perlakuan siklus pertama tahap perlakuan tindakan, siswa diberikan media bantu bola gymnastic sebagai alat pembelajaran meroda dan hasil belajar rata - rata dari subjek 24 siswa diperoleh hasil belajar sebanyak $74,8 \%$. Hasil itu diperoleh dari akumulasi ketiga aspek: psikomotor, afektif dan kognitif. Pada perlakuan siklus kedua rata - rata dari subjek 24 siswa diperoleh hasil belajar sebanyak 80,1\%. Maka dapat disimpulkan bahwa pada penelitian tahap siklus kedua ada peningkatan hasil belajar dari subjek 24 siswa sebanyak $5,3 \%$.
\end{abstract}

Kata kunci: meroda, bola gymnastic

\section{PENDAHULUAN}

Undang-Undang Sistem

Pendidikan Nasional Pasal 1 ayat 1 yang menyatakan bahwa: "Pendidikan adalah usaha sadar untuk menyiapkan peserta didik melalui kegiatan bimbingan, pengajaran, dan atau latihan bagi peranannya di masa yang akan datang". Pendidikan bukan hanya sebagai sarana untuk menyiapakan individu bagi kehidupannya di masa depan, tetapi juga untuk kehidupan anak masa sekarang yang sedang mengalami perkembangan menuju ke tingkat kedewasaan. Pada proses pendidikan, anak aktif mengembangkan diri dan guru aktif membantu menciptakan kemudahan untuk perkembangan yang optimal tersebut. Pendidikan anak sangat penting dan perlu diperhatikan secara serius, karena pendidikan anak merupakan tonggak atau fondasi dimasa mendatang. Pendidikan yang diterapkan dengan benar akan mengembangkan anak dengan baik, sebaliknya apabila pendidikan diterapkan tidak sesuai dengan perkembangan anak, maka anak akan mengalami kesulitan dalam belajar.

Pendidikan Jasmani, Kesehatan dan Rekreasi merupakan bagian penting dari pendidikan secara keseluruhan, bertujuan untuk mengembangkan aspek kebugaran jasmani, keterampilan gerak, keterampilan berfikir kritis, kemampuan 
sosial, penalaran, stabilitas emosional, tindakan moral, aspek pola hidup sehat dan pengenalan lingkungan bersih melalui aktifitas fisik. Pendidikan jasmani dipandang penting untuk diajarkan. Hal ini disebabkan karena melalui pendidikan jasmani, seseorang akan mampu memiliki fisik yang bugar.

Menurut Abduljabar (2012) pendidikan jasmani tidak hanya menyebabkan seorang terdidik fisiknya melainkan terkait dengan aspek kesejahteraan total seperti yang dimaksudkan dengan konsep kebugaran jasmani sepanjang hayat. Keberhasilan proses kegiatan belajar mengajar pada pembelajaran pendidikan jasmani dapat diukur dari keberhasilan siswa yang mengikuti kegiatan tersebut.

Dalam pelajaran Pendidikan Jasmani, Kesehatan dan Rekreasi ada berbagai macam cabang olahraga dan permainan. Salah satu dari cabang olahraga dan permainan tersebut diantaranya adalah senam. Senam merupakan aktivitas jasmani yang efektif untuk mengoptimalkan pertumbuhan dan perkembangan anak. Menurut Pinayungan (dalam Rindawan dkk, 2016) bahwa senam lantai adalah senam dasar, yang latihannya dapat dilakukan untuk keterampilan perorangan dapat dilakukan secara sendiri-sendiri, berkawan ataupun berkelompok.

Menurut Muhajir dkk, (2013) senam dapat diartikan sebagai "setiap bentuk pembelajaran fisik yang disusun secara sistematis dengan melibatkan gerakan-gerakan yang terpilih dan terencana untuk mencapai tujuan tertentu". Sedangkan menurut Nurdini (2013:55-56) senam adalah salah satu cabang olahraga yang mengandalkan aktivitas, baik sebagai olahraga sendiri maupun untuk cabang olahraga lain.

Olahraga ini merupakan salah satu materi dari pendidikan jasmani, kesehatan dan rekreasi di sekolah menengah pertama. Salah satu jenis senam lantai yang diajarkan siswa sekolah yaitu meroda atau baling - baling. Meroda atau gerakan baling - baling merupakan salah satu jenis senam lantai yang dilakukan kesamping untuk empat hitungan, tangan dan kaki berputar seperti baling - baling. Meroda adalah suatu gerakan ke samping dimana pada suatu saat bertumpu atas kedua tangan dengan kaki terbuka lebar (Muhajir; 2007). Gerakan meroda menurut Sayuti Sahara (2003) merupakan latihan dengan tumpuan tangan yang dilakukan secara bergantian yang sangat singkat, selain itu ada saat posisi badan yang terbalik (kepala berada di bawah).

Hamalik dalam Arsyad (2005) mengemukakan bahwa pemakaian media pembelajaran dalam proses belajar mengajar dapat membangkitkan keinginan dan minat yang baru, membangkitkan motivasi dan rangsangan kegiatan belajar, dan bahkan membawa pengaruh psikologis terhadap siswa.

Menurut Santoso, (2013) bola gymnastic adalah sebuah alat bantu olahraga yang banyak kita temui di pusat kebugaran. Alat ini berbentuk seperti bola dengan ukuran berbeda-beda dengan berat kurang lebih satu kilogram yang terbuat dari karet lateks, namun mampu menahan beban hingga 120 kilogram. Bola gymnastic biasanya juga terbuat dari karet pvc yang lembut dan elastis yang diisi dengan udara hingga membentuk bola yang besar, bola besar ini tersedia bermacam-macam ukuran dari diameter $45 \mathrm{~cm}$ sampai $75 \mathrm{~cm}$ (Ashadi, 2015). Gerak dasar meroda bukan merupakan gerakan yang mudah. Hal ini disebabkan karena pada waktu gerakan tersebut siswa harus mempunyai penguasaan teknik dasar meroda dengan baik. Kurangnya pengetahuan tentang tehnik gerakan meroda, rendahnya hasil belajar pada materi gerakan meroda. Dalam kebanyakan kasus yang terjadi siswa 
kurang berani melalukan gerakan meroda karena takut akan terjatuh. Banyak siswa yang merasa takut untuk melaksanakan gerakan meroda sehingga dalam pelaksanaannya siswa kurang optimal melakukan gerakan, akibatnya siswa tidak mampu melakukan gerakan dengan baik dan benar. Karena ketakutannya siswa kurang termotivasi untuk bisa melakukan gerakan meroda bahkan ada siswa yang sama sekali tidak mau melakukan gerakan meroda.

\section{METODE}

Penelitian ini merupakan penelitian tindakan kelas (PTK). Dengan tujuan untuk meningkatkan pembelajaran gerak dasar meroda melalui media bola gymnastic pada siswa kelas VIII MTs. Roudlotul Mutta'allimin. Dapat digambarkan berdasarkan desain di bawah ini:

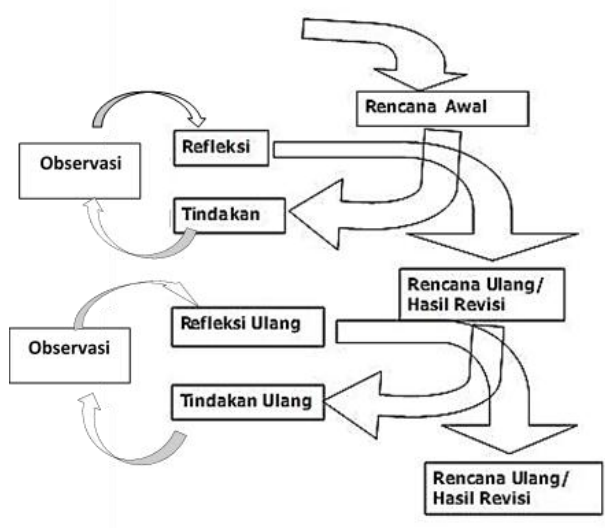

Gambar 1. Desain Penelitian PTK

\section{Populasi dan Sampel}

Populasi dalam penelitian ini adalah Mts Roudlotul Mutta'allimin. Dengan sampel penelitian kelas VIII C yang berjumlah 24 siswa.

\section{Pengumpulan Data}

Dalam penelitian ini peneliti menggunakan teknik pengumpulan data dengan observasi untuk mengetahui kinerja guru dalam proses pembelajaran gerak dasar meroda dan rubrik penilaian hasil belajar gerak dasar meroda siswa.

\section{Analisis Data}

Pengamatan penilaian hasil belajar siswa dilaksanakan di setiap akhir RPP. Analisis data yang digunakan dalam penilaian hasil belajar siswa menggunakan teknik analisis deskriptif kuantitatif dengan persentase. Menurut Sugiyono (2011: 199), statistik deskriptif adalah statistik yang digunakan untuk menganalisis data dengan cara mendeskripsikan atau menggambarkan data yang telah terkumpul sebagaimana adanya tanpa bermaksud membuat kesimpulan yang berlaku untuk umum atau generalisasi. Menurut Sugiyono (2011: 199), Pendekatan Acuan Penilaian (PAP) hasil belajar siswa disusun dengan 5 kategori, yaitu:

1. "sangat baik",

2. "baik",

3. "sedang",

4. "kurang",

5. "kurang sekali".

Setelah diketahui tingkat hasil belajar siswa yang termasuk dalam kategori: "sangat baik", "baik", "sedang", "kurang", dan "kurang sekali", maka akan dapat ditentukan besar persentase dari tiap kategori penilaian tersebut.

\section{HASIL}

\section{Kondisi Awal}

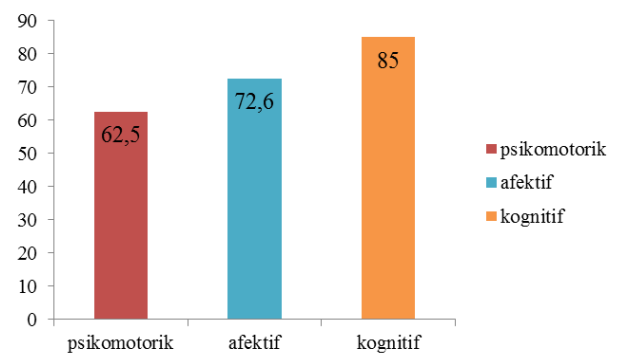

Diagram 1. Hasil Kondisi Awal

Dari hasil perolehan studi awal diatas telah di ketahui nilai-nilai aspek pembelajaran setiap siswa kelas VIII C 
MTs. Roudlotul Muta'allimin sebagai acuan pertama dalam penelitian ini. Dimana rata - rata nilai yang diperoleh pada aspek psikomotorik adalah 62,5 pada aspek afektif adalah 72,6 dan pada aspek kognitif adalah 85 . Kemudian nilai tertinggi dalam satu kelas tersebut adalah 78 dan nilai terendah yang diperoleh dalam satu kelas adalah 70 . Secara keseluruhan nilai rata - rata dari 24 siswa tersebut adalah 73,3\%. Berdasarkan Kriteria Ketuntasan Minimum (KKM) yaitu 75 maka pada studi awal ini hasil pembelajaran siswa kelas VIII C masih belum mencapai KKM yang ada di seklah tersebut. Dari data tersebut diketahui ada 7 siswa yang tuntas belajar dan 17 siswa yang belum tuntas belajar.

Berdasarkan data pada hasil awal studi tersebut peneliti melakukan modifikasi pembelajaran meroda menggunakan media bola gymnastic ke tahap siklus 1.

\section{Siklus I}

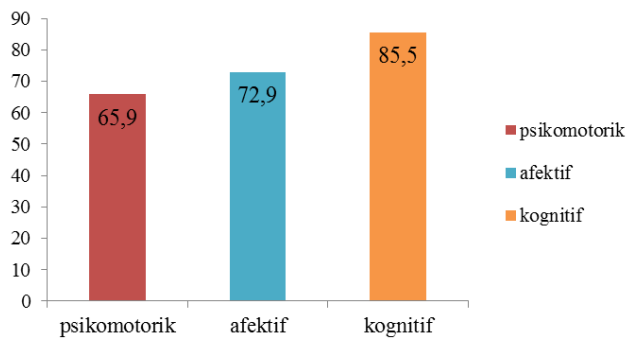

Diagram 2. Hasil Siklus I

Dari hasil perolehan data diatas telah di ketahui nilai-nilai aspek pembelajaran setiap siswa kelas VIII C MTs. Roudlotul Muta'allimin selama proses pembelajaran siklus ke-1. Dimana rata - rata nilai yang diperoleh pada aspek psikomotorik adalah 65,9 pada aspek afektif adalah 72,9 dan pada aspek kognitif adalah 85,5. Kemudian nilai tertinggi dalam satu kelas tersebut adalah 86,1 dan nilai terendah yang diperoleh dalam satu kelas adalah 64,4.
Dapat dibandingkan antara studi awal dan siklus I bahwa studi awal telah diperoleh rata-rata nilai dari 24 siswa kelas VIII C adalah $73,3 \%$ dan hasil nilai rata-rata pada siklus ke 1 adalah $74,8 \%$ maka dapat di simpulkan bahwa ada peningkatan hasil belajar sswa kelas VIII C sebanyak 1,5\%. Peningkatan hasil belajar siswa yang diperoleh pada siklus 1 merupakan hasil dari proses pembelajaran tentang gerak meroda menggunakan media bola gymnastic yang di berikan oleh peneliti, kemudian mampu di cermati dan di paraktekkan siswa dengan baik. Sehingga dalam penilaian pada hasil siklus 1 terkait aspek psikomotorik, afektif dan kognitif siswa mengalami peningkatan hasil.

\section{Siklus II}

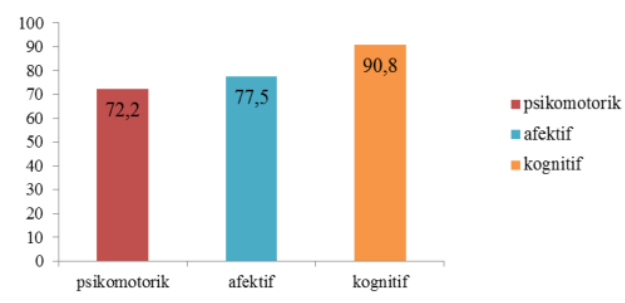

Diagram 3. Hasil Siklus II

Dari hasil perolehan data diatas telah di ketahui nilai - nilai aspek pembelajaran setiap siswa kelas VIII C MTs. Roudlotul Muta'allimin selama proses pembelajaran siklus ke-2. Dimana rata - rata nilai pada aspek psikomotorik adalah 72,2 pada aspek afektif adalah 77,5 dan pada aspek kognitif adalah 90,8 yang diperoleh dari 24 siswa kelas VIII C adalah 80,1 . Kemudian nilai tertinggi dalam satu kelas tersebut adalah 89,7 dan nilai terendah yang diperoleh dalam satu kelas adalah 73,6.

Dapat dibandingkan antara hasil siklus I dan II bahwa pada siklus ke 1 telah diperoleh rata - rata nilai dari 24 siswa kelas VIII C adalah $74,8 \%$ dan hasil nilai rata - rata pada siklus ke 2 adalah $80,1 \%$ maka dapat di simpulkan bahwa ada 
peningkatan hasil belajar siswa kelas VIII C sebanyak 5,3\%. Pada tahap siklus 2 ini peningkatan hasil belajar siswa yang diperoleh merupakan hasil dari proses pembelajaran tentang gerak meroda menggunakan media bola gymnastic yang di berikan oleh peneliti, kemudian mampu di cermati dan di paraktekkan siswa dengan baik. Sehingga dalam penilaian pada hasil siklus 2 terkait aspek psikomotorik, afektif dan kognitif siswa mengalami peningkatan hasil.

\section{Hasil Belajar Siswa}

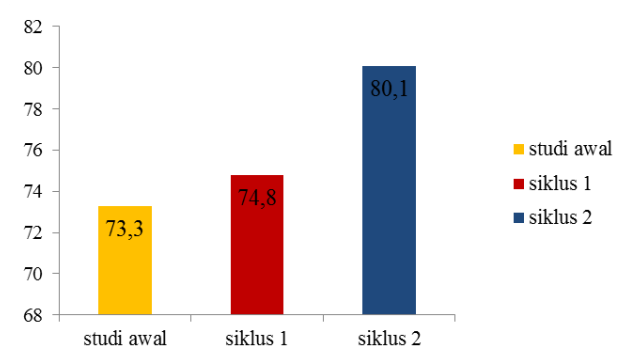

Diagram 4. Hasil Belajar Siswa

Berdasarkan diagram diatas menunjukkan bahwa hasil belajar pada studi awal diperoleh nilai rata - rata 73,3\% dari 24 siswa kelas VIII C, selanjutnya hasil belajar pada siklus ke 1 diperoleh nilai rata - rata $74,8 \%$ dan pada siklus ke 2 diperoleh nilai rata - rata dari 24 siswa adalah $80,1 \%$. Pada studi awal rata - rata hasil belajar siswa yaitu 73,3 , setelah pemberian tindakan tentang meroda menggunakan media bola gymnastic pada siklus 1 hasil belajar siswa terkait aspek psikomotorik, afektif dan kognitif mengalami peningkatan sebanyak $1,5 \%$. Rata - rata yang diperoleh dari 24 siswa adalah 74,8\%. Karena pada tindakan siklus 1 hasil belajar siswa masih dibawah $\mathrm{KKM}$, maka dilanjutkan pada tahap siklus 2 dalam pemberian pembelajaran meroda menggunakan media bola gymnastic. Hasil pembelajaran yang diperoleh pada siklus 2 siswa kelas VIII C adalah $80,1 \%$. Hasil tersebut menunjukkan adanya peningkatan terkait aspek psikomotorik, afektif dan kognitif pada siklus 2 sebanyak $5,3 \%$.

\section{PEMBAHASAN}

Data studi awal yang diperoleh sebelum perlakuan siklus ke-1 adalah 7 siswa nilai hasil belajar diatas KKM dan 17 siswa nilai dibawah KKM. Dimana studi awal tersebut merupakan acuan pertama penulis dalam pelaksanaan penelitian terhadap gerak meroda dengan media bantu bola Gymnastic.

Pelaksanaan siklus ke-1 dimulai dengan tahap observasi kemampuan siswa dalam gerak meroda. Selanjutnya pemberian pembelajaran terhadap siswa tentang indikator - indikator gerak meroda dan peneliti memasukkan media bola gymnastic sebagai alat bantu pembelajaran. Tahap terakhir pada siklus pertama adalah penilaian hasil belajar siswa dimana telah diperoleh data hasil belajar pada siklus ke 1 mulai dari nilai aspek psikomotorik, aspek afektif, dan aspek kognitif. Dari 24 siswa yang nilainya tuntas di atas KKM sebanyak 9 siswa, dan 15 siswa yang nilainya belum tuntas (dibawah KKM). Maka dari itu penelitian berlanjut ke siklus kedua untuk menuntaskannya.

Perlakuan siklus ke-2 dimulai dengan langkah - langkah yang sama seperti pada siklus pertama. Untuk siklus ke 2 dalam proses pembelajaran gerak meroda siswa diberikan tindakan menggunakan media bantu bola gymnastic yang bertujuan untuk memudahkan siswa dalam pelaksanaan gerak meroda. Tahap terakhir adalah penilaian pada siklus ke-2 dan diperoleh hasil data seperti pada lembar hasil penelitian diatas. Dari 24 siswa yang nilainya di atas KKM sebanyak 20 siswa dan 4 siswa masih belum tuntas.

Perbandingan ketuntasan belajar siswa dari siklus pertama adalah 0 anak dan siklus kedua adalah 20 anak. Terdapat peningkatan hasil belajar siswa 
terhadap gerak meroda sebanyak 11 siswa. Adapun peningkatan yang signifikan ini di pengaruhi oleh peningkatan terkait aspek psikomotorik, afektif dan kognitif siswa sebanyak 5,3\%. Pembelajaran yang di berikan peneliti mampu dicermati dan dipraktekkan dengan baik. Dimana pada siklus ke-2 siswa mampu menerapkan indikator indikator seluruh aspek pembelajaran dengan lebih baik.

Dalam proses belajar siswa mampu berperan aktif dalam mengikuti di setiap pembelajaran yang diberikan oleh peneliti. Hampir seluruh siswa mampu menyelesaikan tugas yang diberikan oleh peneiti dengan baik. Selain itu dalam proses belajar mampu tercipta suasana yang menyenangkan, hal itu di tunjukkan oleh semangat siswa dalam mengikuti pembelajaran, keseriusan siswa dalam menerima dan memperhatikan materi, dan siswa mampu menyelesaikan tugas yang diberikan dengan baik.

Hasil belajar siswa mengalami peningkatan. Peningkatan tersebut dibuktikan dengan hasil pada siklus 2 lebih baik dibandingkan dengan studi awal ataupun hasil pada siklus 1 .

Adapun penelitian tentang gerak meroda pada penelitian sebelumnya dalam skripsi Sulistiyo (2015) bahwa, penelitian tentang gerak meroda menggunakan dua tindakan siklus terbukti ada peningkatan keberhasilan dalam prses pembelajaran yang diberikan dengan hasil perkembangan belajar gerak dasar meroda siswa yang signifikan di siklus dua dibandingkan dengan hasil data kasus dan hasil belajar di siklus satu. Hasil belajar gerak dasar meroda di siklus dua telah sesuai dengan indikator keberhasilan, yaitu sebanyak 23 siswa atau sebesar $82,14 \%$ dari keseluruhan 28 siswa kelas V SD Negeri Klegung, Kecamatan Tempel, Kabupaten Sleman masuk dalam kategori penilaian "baik" dan "sangat baik".

\section{KESIMPULAN}

Setelah memperoleh data hasil observasi studi awal dimulailah pelaksanaan siklus pertama, dimana siklus ini dimulai dari tahap rencana awal, tindakan, obsevasi, dan refleksi. Dalam proses tindakan peneliti memberikan media bantu bola gymnastic. Maka telah di peroleh hasil data rata - rata 24 siswa adalah $74,8 \%$.

Karena hasil siklus pertama belum mencapai indikator keberhasilan yaitu KKM 75, maka penelitian ini dilanjutkan ke tahap siklus kedua. Pada siklus kedua dilakukan tahap perencanaan awal, tindakan, observasi, dan refleksi. Dalam proses tindakan peneliti memberikan media bantu bola gymnastic. Dan telah diperoleh hasil data rata - rata 24 siswa adalah $80,1 \%$.

Hasil belajar gerak meroda melalui media bantu bola gymnastic sebanyak 20 siswa dari keseluruhan 24 siswa atau sebesar $81,3 \%$ tuntas dalam proses belajar yang sesuai dengan indikator keberhasilan, yaitu KKM 75 dan minimal $80 \%$ dari seluruh siswa dalam satu kelas telah menuntaskan proses belajar dengan baik.

Karena waktu penelitian yang di berikan hanya 1 bulan maka penelitian ini di maksimalkan untuk dua siklus saja. Namun, hasil penelitian menunjukkan ada peningkatan sebanyak $5,3 \%$ dalam proses belajar siswa melalui tahap siklus pertama sampai siklus kedua.

\section{DAFTAR PUSTAKA}

Arikunto S. 2010. Metodologi Penelitian. Jakarta. Penerbit Renika Cipta.

Anggriawan J. 2017. Pengetahuan Instruktur Kebugaran Tentang Alat Olahraga Gym Ball. Mojokerto. Universitas Negeri Surabaya.

Bernada A. 2013. Tingkat Kemampuan Melakukan Guling Depan.Yogyakarta. Fakultas IImu 
Keolahragaan Universitas Negeri Yogyakarta.

Budi L. 2015. Upaya meningkatkan keberanian meroda. Kebumen

Hanafiah, dkk. 2010. Konsep Strategi Pembelajaran. Refika Aditama. Bandung.

Harini W. 2013. Pengembangan Pembelajaran Uji Diri Meroda. Surakarta. Universitas Muhammadiyah.https://mybest.id/22519/ 10 Rekomendasi Gym Ball Terbaik (Terbaru Tahun 2018)

Indrawan R. 2016. Peninkatan Hasil Belajar Senam Lantai. Surakarta. UNS.

Kartika Heny W, dkk. 2016. Pengembangan Pembelajaran Senam Lantai. Malang. FIK. Universitas Negeri Malang.

Margono A. 2009. Senam. Surakarta: UNS Press

Mawla H. 2016. Tingkat Keterampilan Guling Depan. Yogyakarta. Fakultas IImu Keolahragaan Universitas Negeri Yogyakarta.

Nasirullah M. 2013. Penetapan KKM. Malang. UMM

Ngadiyanto. 2016. Didaktikum : Jurnal Penelitian Tindakan Kelas. Pekalongan

Rahman K. 2014. Upaya Meningkatkan Keterampilan Gerak Meroda. Lampung. Universitas Lampung.

Rindawan, dkk. 2016. Jurnal IImiah Mandala Educatio, Mataram.

Saragih Adi J, dkk. 2015. upaya peningkatan hasi Ibelajar meroda. Medan. Prodi Pendidikan Jasmani Kesehatan Dan Rekreasi STOK.

Sudrajat A. 2008. Penetapan KKM

Sudyantoro H. 2015. Upaya Peningkatan Pembelajaran Gerak Dasar Meroda. Yogyakarta. UNY.

Suharyanto. 2015. Peningkatan Pembelajaran Senam Lantai. Yogyakarta. Fakultas IImu
Keolahragaan Universitas Negeri Yogyakarta.

Undang-Undang Republik Indonesia Nomor 20. 2003. Tentang Sistem Pendidikan Nasional. Jakarta.

Wibowo S. 2015. Meningkatkan Pembelajaran Senam Lantai Meroda. Yogyakarta. Fakultas IImu Keolahragaan Universitas Negeri Yogyakarta

Wuryantoro K, dkk. 2011. Jurnal

Pendidikan Jasmani Indonesia .Yogyakarta. UNY. 